\title{
Molecular PET imaging of HSV1-tk reporter gene expression using $\left[{ }^{18} \mathrm{~F}\right] \mathrm{FEAU}$
}

\author{
Suren Soghomonyan ${ }^{1}$, Amin Hajitou ${ }^{1}$, Roberto Rangel ${ }^{1}$, Martin Trepel $^{2}$, Renata Pasqualini ${ }^{1}$, Wadih Arap ${ }^{1}$, \\ Juri G Gelovani ${ }^{1}$ \& Mian M Alauddin ${ }^{1}$
}

\begin{abstract}
${ }^{1}$ The University of Texas M.D. Anderson Cancer Center, 1515 Holcombe Boulevard, Houston, Texas 77030, USA. ${ }^{2}$ University of Freiburg Medical Center, Hugstetter Strasse 55, D-79106 Freiburg, Germany. Correspondence should be addressed to M.M.A. (alauddin@di.mdacc.tmc.edu).

Published online 8 March 2007; doi:10.1038/nprot.2007.49

Non-invasive imaging of transgene expression requires the appropriate combination of a reporter gene and a reporter probe. $\left[{ }^{18} \mathrm{~F}\right] \mathrm{FEAU}$ positron emission tomography (PET) is used for the assessment of herpes simplex virus type-1 thymidine kinase gene expression. Hybrid AAV phage (termed AAVP) can be adapted to transduce mammalian cells by targeting to a specific receptor. We evaluated a targeted AAVP vector using $\left[{ }^{18} \mathrm{~F}\right] \mathrm{FEAU}$ PET. This protocol describes $\left[{ }^{18} \mathrm{~F}\right] \mathrm{FEAU}$ production and dosing, micro-PET imaging and image analysis. 2-Deoxy-2-trifluoromethanesulfonyl-1,3,5-tri-0-benzoyl- $\alpha$-D-ribofuranose is radio-fluorinated, converted into its 1-bromo derivative and coupled with protected 5-ethyl uracil. The coupled product is hydrolyzed and purified using HPLC. Tumorbearing animals targeted with either retroviral or AAVP vectors are anesthetized and injected with $\left[{ }^{18} \mathrm{~F}\right] \mathrm{FEAU}(0.1 \mathrm{mCi}$ per mouse); this is followed $2 \mathrm{~h}$ after injection by imaging on a micro-PET. Production of $\left[{ }^{18} \mathrm{~F}\right] \mathrm{FEAU}$ requires approximately $3.5 \mathrm{~h}$ from the end of bombardment. PET imaging studies require $2-3 \mathrm{~h}$ (depending on the number of animals) after synthesis of $\left[{ }^{18} \mathrm{~F}\right] \mathrm{FEAU}$.
\end{abstract}

\section{INTRODUCTION}

A paradigm for non-invasive imaging of transgene expression involves the appropriate combination of a reporter gene and a reporter substrate or probe ${ }^{1-3}$. This imaging paradigm is essentially an in vivo radiotracer enzyme assay, where the reporter gene product (an enzyme) selectively converts a reporter probe into a metabolite that is trapped within the transduced cells. Model systems have been established and validated in tissue culture and experimental animals using herpes simplex virus type-1 thymidine kinase (HSV1-tk) gene as a reporter gene and radiolabeled pyrimidine nucleoside analogs and acycloguanosine analogs as reporter probes ${ }^{4-10}$. The use of this paradigm and the reporter gene technology have been extended. Reporter genes can be used (i) to image vector targeting and level of suicide gene (HSV1-tk) expression ${ }^{11}$; (ii) to image the regulation of endogenous genes and signal-transduction pathways ${ }^{12-16}$; and (iii) to monitor and quantitatively assess the expression of a second transgene that is cis-linked to the reporter gene by an internal ribosome entry site sequence ${ }^{14,15}$.

We developed the acycloguanosine derivatives $\left[{ }^{18} \mathrm{~F}\right] \mathrm{FHPG}$ and $\left[{ }^{18} \mathrm{~F}\right] \mathrm{FHBG}^{5-8}$ and a series of ${ }^{18} \mathrm{~F}$-labeled pyrimidine nucleoside derivatives, including $\left[{ }^{18} \mathrm{~F}\right] \mathrm{FMAU},\left[{ }^{18} \mathrm{~F}\right] \mathrm{FIAU},\left[{ }^{18} \mathrm{~F}\right] \mathrm{FFAU}$, $\left[{ }^{18} \mathrm{~F}\right] \mathrm{FCAU},\left[{ }^{18} \mathrm{~F}\right] \mathrm{FBAU}$ and $\left[{ }^{18} \mathrm{~F}\right] \mathrm{FEAU}$ (Fig. 1), for positron emission tomography (PET) imaging of HSV1-tk gene expres$\operatorname{sion}^{17-22}$. We have investigated these pyrimidine and guanosine analogs in human colon cancer cells (HT-29) to compare their efficacies $^{6-8,18,20-22}$. The pyrimidine derivatives have been found to have two advantages over the acycloguanosine derivatives. First, pyrimidine nucleosides are much more (log-order) sensitive than the guanosine derivatives $\left[{ }^{18} \mathrm{~F}\right] \mathrm{FHPG}$ and $\left[{ }^{18} \mathrm{~F}\right] \mathrm{FHBG}^{4,20}$. Second, pyrimidine derivatives follow renal clearance ${ }^{20}$, and therefore the background activity is negligible, whereas $\left[{ }^{18} \mathrm{~F}\right] \mathrm{FHBG}$ is cleared through a hepatobiliary pathway, resulting in the retention of large amounts of radioactivity in the intestine and other organs ${ }^{13,16}$. Among the pyrimidine nucleosides, $\left[{ }^{18} \mathrm{~F}\right] \mathrm{FFAU}$ has the highest sensitivity and specificity for HSV1-tk, and FEAU has lower sensitivity and specificity than FFAU in HT-29 cells $^{22}$. Other than

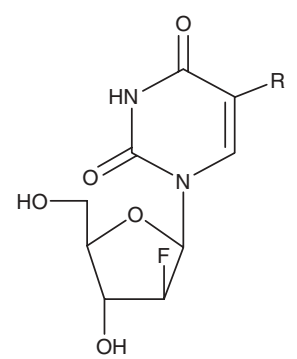

FFAU; $\mathrm{R}=\mathrm{F}$ FCAU; $\mathrm{R}=\mathrm{Cl}$ FBAU; $\mathrm{R}=\mathrm{B}$ FIAU; $\mathrm{R}=\mathrm{I}$ FMAU; $\mathrm{R}=\mathrm{CH}_{3}$ FEAU; $\mathrm{R}=\mathrm{C}_{2} \mathrm{H}_{5}$

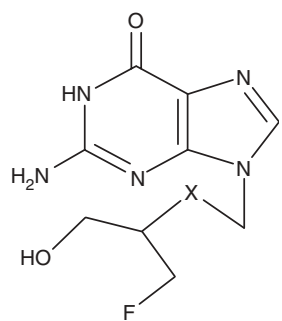

FHPG; $X=0$ FHBG; $X=\mathrm{CH}_{2}$
Figure 1 | Chemical structure of the nucleoside analogs, with abbreviated names.

FFAU and FEAU, pyrimidine analogs have some non-specific uptake $^{22}$. These results suggest that FFAU and FEAU are the imaging agents most specific for HSV1-tk. However, when we compared these tracers in human breast cancer cells (MDA-MB-468), total uptake of $\left[{ }^{18} \mathrm{~F}\right] \mathrm{FFAU}$ in HSV1-tk-expressing cells was 150 -fold less than that of FEAU ${ }^{23}$. This result suggests that $\left[{ }^{18} \mathrm{~F}\right] \mathrm{FEAU}$ may be the best choice of PET imaging agent for HSV1-tk gene expression in terms of sensitivity and specificity; however, further studies are necessary to investigate the efficacy of these nucleosides in a variety of cancer cells. Recently, others have demonstrated that FEAU has the highest uptake ratio between tk-positive transduced cells and wild-type cells when compared with FHBG, FIAU, FMAU, FHPG and $\mathrm{FLT}^{24}$. It has been reported that a combination of high accumulation and high selectivity for both HSV1-tk and HSV1-sr39tk makes FEAU a promising candidate for PET imaging of $H S V$-tk gene expression ${ }^{25}$. $\left[{ }^{18} \mathrm{~F}\right] \mathrm{FEAU}$ has also been used to monitor the response of tumors using PET after systemic Sindbis/tk (vector) treatment as a basis for determining the levels of tissue distribution of vectors in living animals ${ }^{26}$. 
Bacteriophages (phages) are bacterial viruses that can be adapted to transduce mammalian cells by targeting to a specific receptor ${ }^{27-32}$. We have recently developed and evaluated a novel phage-based targeted vector, a genetic chimera of filamentous phage and recombinant AAV (termed AAVP) ${ }^{28}$. We have demonstrated that it is possible to assess targeted AAVP vectors non-invasively in experimental tumors. The expression of the reporter gene (HSV1-tk) can be successfully imaged using $\left[{ }^{18} \mathrm{~F}\right]$ FEAU and PET in pre-clinical tumor models ${ }^{28}$. This protocol covers the following aspects of this approach. (i) Radiotracer $\left(\left[{ }^{18} \mathrm{~F}\right] \mathrm{FEAU}\right)$ production is a seven-step synthesis, shown schematically in Figure 2. (ii) This is followed by radiotracer dosing and administration. (iii) Animal preparation and tumor growth: use nine mice per group to generate statistically meaningful results. Animals are divided into two groups, with group 1 receiving targeted AAVP vector and group 2 receiving non-targeted AAVP vector administration. Negative control groups consist of mice with tumors produced from parental tumor cells; positive controls are mice with tumors produced from tumor cells stably transfected with HSV1-tk. (iv) After micro-PET calibration, the animals are imaged using $\left[{ }^{18} \mathrm{~F}\right] \mathrm{FDG}\left({ }^{18}\right.$ fluoro-2-deoxyglucose) PET to observe viable tumor cells on day 4 after the AAVP vector administration. Animals are then imaged with $\left[{ }^{18} \mathrm{~F}\right] \mathrm{FEAU}$ PET to observe HSV1-tk gene expression (from day 5 onward). (v) The protocol ends with image reconstruction, analysis and interpretation ${ }^{33}$.

\section{MATERIALS}

\section{REAGENTS}

- Cells (see REAGENT SETUP)

- Minimal essential medium (MEM; Irvine Scientific, Santa Ana, CA)

- DMEM (Gibco, Gaithersburg, MD)

$\cdot$ L-GIn

- Penicillin/streptomycin

- Animals (see REAGENT SETUP)

- Oxygen-18 enriched water $\left(\left[{ }^{18} \mathrm{O}\right] \mathrm{H}_{2} \mathrm{O}\right.$ ) (any suitable source as used by cyclotron operators)

$\cdot \mathrm{K}_{2} \mathrm{CO}_{3}$ (Aldrich, St. Louis, MO) ! CAUTION Irritant.

- Kryptofix 2.2.2 (Aldrich) ! CAUTION Toxic, use in a fume hood.

- Anhydrous acetonitrile (MeCN; Aldrich) ! CAUTION Flammable liquid, toxic.

-Ethyl acetate (EtOAc; Aldrich) ! CAUTION Flammable liquid, irritant.

$\cdot 1,3,5$-Tri- $O$-benzoyl- $\alpha$-D-ribofuranose (Aldrich)

- Anhydrous pyridine (Aldrich)! CAUTION Irritant, use in a fume hood.

- Trifluoromethane sulfonic anhydride (Aldrich)! CAUTION Corrosive and moisture sensitive.

- Hexane (Aldrich) ! CAUTION Flammable liquid, irritant.

- Acetone (Aldrich) ! CAUTION Flammable liquid, irritant.

- Dichloromethane $\left(\mathrm{CH}_{2} \mathrm{Cl}_{2}\right.$; Aldrich) ! CAUTION Flammable liquid, cancer suspecting agent.

-1,2-Dichloroethane (Aldrich) ! CAUTION Flammable liquid, cancer suspecting agent.

-1,1,1,3,3,3-Hexamethyldisilazane (Aldrich) ! CAUTION Flammable liquid, corrosive.

- Chlorotrimethylsilane (TMSCl; Aldrich) ! CAUTION Flammable liquid.

-5-Ethyl uracil (Aldrich)! CAUTION Irritant.

- Hydrogen bromide in acetic acid ( $\mathrm{HBr} / \mathrm{AcOH}, 30 \%$ (wt/wt); Aldrich)

I CAUTION Highly toxic, use in fume hood.

-Hydrochloric acid (HCl, $1 \mathrm{M}$; Aldrich)! CAUTION Highly toxic and corrosive.

- Sodium methoxide (NaOMe, 0.5 M; Aldrich) ! CAUTION Flammable and corrosive.

- Methanol (MeOH; Aldrich)! CAUTION Flammable and toxic.

- Toluene (Aldrich)! CAUTION Flammable and toxic.

- Saline (Abbott Laboratories, Chicago, IL)

-2-Deoxy-2-trifluoromethanesulfonyl-1,3,5-tri-O-benzoyl- $\alpha$-D-ribofuranose 1; prepared in-house ${ }^{17,19,34,35}$ (see NMR data)

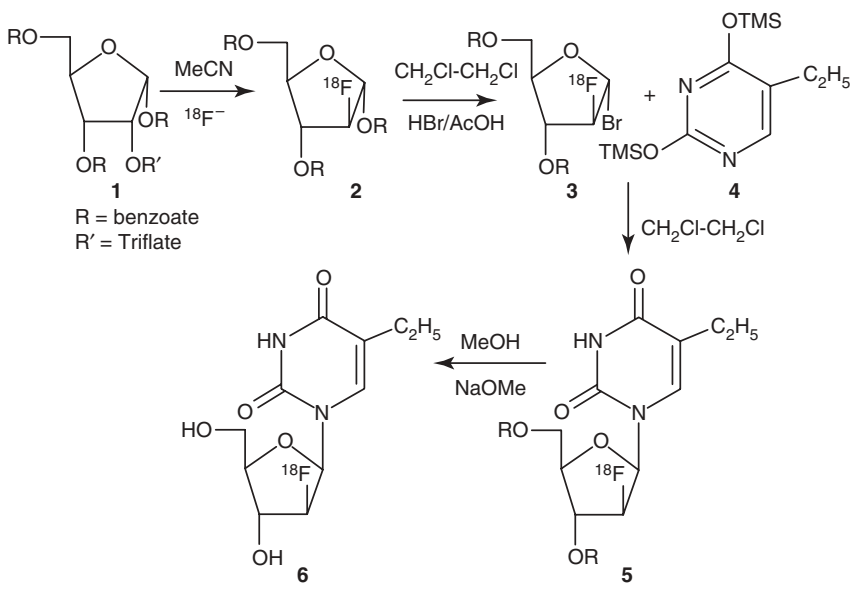

Figure 2 | Synthetic scheme for $\left[{ }^{18} \mathrm{~F}\right] \mathrm{FEAU}$. This scheme represents total synthesis of $\left[{ }^{18} \mathrm{~F}\right] \mathrm{FEAU}$, including its precursor and all intermediates. Cold standard compound, FEAU, can be prepared following this scheme.

See ref. 33 for methods for (i) the cloning and generation of the targeted AAVP vector; (ii) transduction of mammalian cells in culture by the targeted AAVP vector and specific inhibition using synthetic peptides; (iii) real-time transgene expression in mouse models after systemic administration.
- Compound 2 (see REAGENT SETUP)

- Standard solution of FEAU ( $1 \mathrm{mg} \mathrm{ml}^{-1}$ in $10 \% \mathrm{MeCN} /$ water (vol/vol)); prepared in-house ${ }^{19,35,36}$ (see REAGENT SETUP)

$\cdot 2,4$-Bis-trimethylsilyl-5-ethyl uracil 4; prepared in-house ${ }^{19}$ (see PROCEDURE)

- RGD-4C AAVP-HSV1 vector ${ }^{28}$

- Non-targeted AAVP-HSV1-tk vector ${ }^{28}$

EQUIPMENT

- Round-bottomed flasks (100 $\mathrm{ml}$ and other sizes)

- Pear-shaped flask (15 ml)

$\cdot$ V-vials $(5 \mathrm{ml})$

- Rotary evaporator

- Rubber septum

- Aluminum seals

- Crimper

- Thin layer chromatography (TLC) plates

• HPLC system (see EQUIPMENT SETUP)

- TLC developing jar

- High-vacuum pump (see EQUIPMENT SETUP)

- Vacuum manifold

- Flash chromatographic column

- Silica gel

- Reflux condenser

- Glass adapter

- Needles

- Syringe (gas tight)

- Regular glass and plastic syringe (Becton Dickinson)

- Teflon tubing (flanged), connectors and end fittings

- Inert gas (argon or nitrogen)

- Gas flow meter

- Balloons

- Silica gel Sep-Pack cartridge (900 mg; Alltech Associates)

- Anion exchange cartridge to trap the $\left[{ }^{18} \mathrm{~F}\right]$ fluoride from $\left[{ }^{18} \mathrm{O}\right] \mathrm{H}_{2} \mathrm{O}(\mathrm{ABX}$, Germany, cat. no. chromafix 30PS-HCO3); use a setup similar to that used in the production of $\left[{ }^{18} \mathrm{~F}\right] \mathrm{FDG}$

- Millipore filter $(0.22 \mu \mathrm{m}$; Millipore)

- Dose calibrator (Capintec) and a survey meter (any suitable make)

- Micro-PET scanner (R-4; Concord Microsystems) (see EQUIPMENT SETUP) 
- Cyclotron or a source of $\left[{ }^{18} \mathrm{~F}\right]$ fluoride (GE or any other suitable make)

- Radiation badge including ring badge

- Hot cell (to perform radiochemical synthesis) with manipulators

-Semi-automated chemistry box (see EQUIPMENT SETUP)

- One column C18 reverse-phase Econosil semi-preparative column

$\left(10 \times 250 \mathrm{~mm}^{2}\right)$ for purification (Alltech Associates)

- One analytical column C18 reverse-phase Econosil $\left(4 \times 250 \mathrm{~mm}^{2}\right)$ for QC analysis (Alltech Associates)

- NMR spectrometer or a source for chemical analysis of the precursor compound

- HPLC column (see EQUIPMENT SETUP)

REAGENT SETUP

Compound 2 Preparation of compound 2 is performed in the cyclotron area using an FDG box (GE) or similar.

$\mathrm{K}_{2} \mathrm{CO}_{3} /$ kryptofix solution Prepare a stock solution of $\mathrm{K}_{2} \mathrm{CO}_{3} /$ kryptofix 2.2.2 by mixing a solution of kryptofix 2.2.2 $\left(12 \mathrm{mg} \mathrm{ml}^{-1}\right.$ in $\left.\mathrm{MeCN}\right)$ and $\mathrm{K}_{2} \mathrm{CO}_{3}\left(2.75 \mathrm{mg} \mathrm{ml}^{-1}\right.$ in water) in a ratio of $80: 20(\mathrm{vol} / \mathrm{vol})$, and store this solution in a refrigerator as a shelf reagent for routine use (discard after 6 months).

Standard solution of cold FEAU Prepare a stock solution of cold FEAU, $1 \mathrm{mg} \mathrm{ml}^{-1}$ HPLC solvent (10\% MeCN in water), and store this solution in a refrigerator. FEAU can be synthesized according to the previously reported method $^{35,36}$ or following the synthetic scheme in Figure 2.

Cells Any cancer cells can be used ${ }^{7,8,18}$. For phage vector-targeted studies, we have used the following cell lines: Kaposi's sarcoma KS1767 (ATCC, Manassas, VA), EF43-FGF4 mouse mammary tumor cells, DU145 prostate carcinoma cells and UC3 bladder carcinoma cells ${ }^{28}$. The Kaposi's sarcoma cells were maintained in MEM; the other cell lines were cultured in DMEM. All media were supplemented with 10\% FBS (Gibco), L-GIn and penicillin/streptomycin. All the tumors established by these cells in mice responded to systemic administration of targeted RGD-4C AAVP-HSV1-tk.

Animals To induce s.c. tumors, use athymic or nude mice. We used either female (6-week-old) mice for stably transduced tumor implantation with HT-29 cells or male (1-month-old) mice for AAVP vector HSV1-tk gene expression studies. $\triangle$ CRITICAL Approval of the protocol by the appropriate Institutional Animal Care and Use Committee is required.

\section{EQUIPMENT SETUP}

Semi-automated chemistry box (custom made, Fig. 3) used for preparation of compounds 3, 5 and $\mathbf{6}$ (Fig. 2). Check the gas flow from the argon or nitrogen tank through the box to ensure that all lines are clear and there is no leak in the system. Upload $\mathrm{HBr}$ /acetic acid, toluene $(0.5 \mathrm{ml})$, compound 4, $\mathrm{NaOMe} / \mathrm{MeOH}$ $(0.4 \mathrm{ml})$ and HPLC solvent (10\% MeCN/water, $1.2 \mathrm{ml}$, containing $0.1 \mathrm{ml} 1 \mathrm{~N}$ $\mathrm{HCl})$ in the reserve vials.

HPLC The production of $\left[{ }^{18} \mathrm{~F}\right] \mathrm{FEAU}$ requires two HPLC systems, each with a UV detector (e.g., Waters or Agilent) and a radioactivity detector (Bioscans, Washington, DC). One system is for purification and the other is for quality control analysis. UV wavelength is $254 \mathrm{~nm}$.

HPLC columns On the day of the experiment, equilibrate HPLC columns, both semi-preparative and analytical, with the appropriate HPLC solvent $(10 \%$ $\mathrm{MeCN} /$ water) before starting the radiosynthesis of $\left[{ }^{18} \mathrm{~F}\right] \mathrm{FEAU}$. Set up the UV lamp at $254 \mathrm{~nm}$. Inject the cold standard solution of FEAU into the HPLC, elute (isocratic) with $10 \% \mathrm{MeCN}$ solvent $\left(4 \mathrm{ml} \mathrm{min}^{-1}\right.$, semi-preparative; $1 \mathrm{ml} \mathrm{min}^{-1}$, analytical) and record the retention time of FEAU in both the semi-preparative and analytical HPLC systems.

High-vacuum pump Set up the high vacuum pump with the cooling trap filled with dry ice and isopropanol.

Micro-PET scanner Calibrate the micro-PET animal scanner (Concord Microsystems, R-4) according to the manufacturer's protocol.

\section{PROCEDURE}

\section{Radiotracer $\left(\left[{ }^{18} \mathrm{~F}\right] \mathrm{FEAU}\right)$ production: preparation of precursor, 2-deoxy-2-trifluoromethanesulfonyl-1,3,5-tri-0-benzoyl- $\alpha$ -} D-ribofuranose 1

1) Dissolve 1,3,5-tri-0-benzoyl- $\alpha$-D-ribofuranose $(1.0 \mathrm{~g})$ in dry pyridine $(20 \mathrm{ml})$ in a round-bottomed flask $(100 \mathrm{ml})$ containing a magnetic bar under argon and cool to $0{ }^{\circ} \mathrm{C}$ in an ice bath.

! CAUTION Perform experiments in a fume hood for chemical synthesis, and use gloves for handling toxic chemicals.

2| Add trifluoromethane sulfonic anhydride (1.3 equiv.), stir the solution for $15 \mathrm{~min}$ at $0{ }^{\circ} \mathrm{C}$, warm to room temperature $\left(\sim 22{ }^{\circ} \mathrm{C}\right)$ and continue stirring for another hour. Monitor the reaction by TLC as follows: transfer a small aliquot of the reaction mixture using a dry syringe to a small flask, pump off pyridine under vacuum and re-dissolve in $\mathrm{CH}_{2} \mathrm{Cl}_{2}$. Spot the solution using a capillary tube on the TLC plate and develop the plate in a developing jar using 15\% EtOAc/hexane (vol/vol). Check the plate under a UV lamp. The $R_{\mathrm{f}}$ values are 0.4 for the starting material and 0.5 for the product.

3| When the reaction is complete (by TLC), remove pyridine using a vacuum pump, chromatograph the crude product on a silica gel column $(20 \times 3 \mathrm{~cm}$, approximately $100 \mathrm{~g})$ and elute the column with $15 \%$ EtOAc/hexane at a flow rate of $20 \mathrm{ml} \mathrm{min}^{-1}$.

4 Collect fractions $(10 \mathrm{ml}$ ) until the compound is completely eluted (check fractions by spotting on a silica gel plate and visualizing under a UV lamp).

5| Combine the fractions that match with the product $\left(R_{\mathrm{f}}=0.5\right)$ in a round-bottomed flask and evaporate solvent using a rotary evaporator.

Figure 3 | A schematic drawing of the chemistry box for coupling ${ }^{18} \mathrm{~F}$-labeled sugar with the protected 5 -ethyl uracil in $\left[{ }^{18} \mathrm{~F}\right] \mathrm{FEAU}$ synthesis. The first part (preparation of $\left[{ }^{18} \mathrm{~F}\right]$ sugar, compound 2 ) is performed on a separate box, such as an FDG box. This box has solenoid valves (NR, $24 \mathrm{~V} \mathrm{DC,} \mathrm{P/N} \mathrm{HP225K032)}$ operated using a remote-control switch box. Each solenoid valve opens a $\mathrm{v}$-vial to transfer reagents from the $\mathrm{v}$-vial to the reaction vial $\left(\left[{ }^{18} \mathrm{~F}\right]\right.$ sugar). The ${ }^{18} \mathrm{~F}$-labeled sugar produced is then passed through a Sep-Pack (silica) cartridge. The cartridge is eluted with EtOAc and collected in the reaction vial. The solvent is evaporated using a pump under a flow of nitrogen or argon. $\mathrm{HBr}$ /acetic acid and $\mathrm{CH}_{2} \mathrm{Cl}-\mathrm{CH}_{2} \mathrm{Cl}$ are added to the dry sugar. Subsequently, toluene, compound 4, $\mathrm{NaOMe}$ and HPLC solvents are added sequentially, as necessary, using the remote-control switch box.

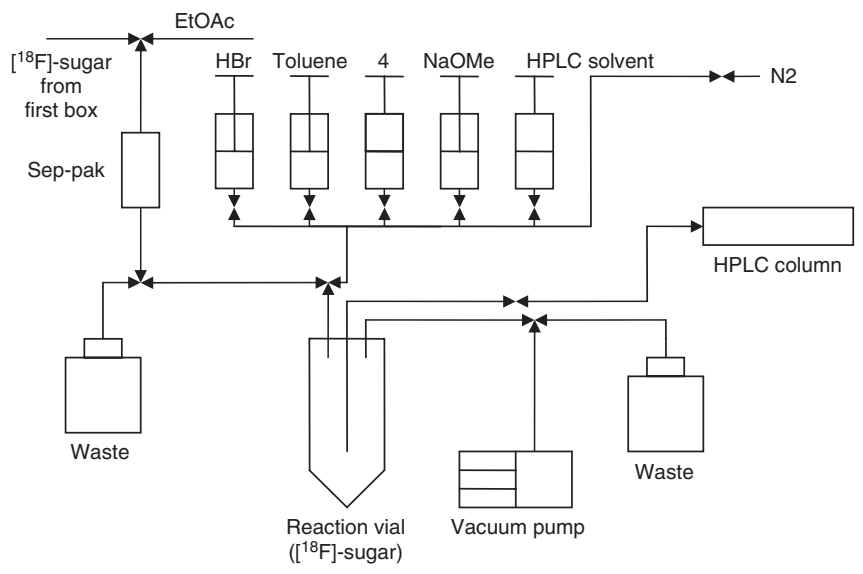


6| Connect the flask to a high-vacuum pump and continue pumping for approximately $4 \mathrm{~h}$ (compound is a white solid).

7| Check the identity of the white solid product using ${ }^{1} \mathrm{H}$ NMR and ${ }^{19} \mathrm{~F}$ NMR spectroscopy, and compare the results with those reported previously ${ }^{34,35}$ (see analytical data).

8| Divide the product into 5-mg aliquots in small vials and seal the vials under argon.

PAUSE POINT Store the precursor at $4{ }^{\circ} \mathrm{C}$ in a desiccator for future radio-fluorination.

? TROUBLESHOOTING

Radiotracer ( $\left.\left.{ }^{18} \mathrm{~F}\right] \mathrm{FEAU}\right)$ production: preparation of 2,4-bis-trimethylsilyl-5-ethyl uracil 4

9| Weigh $50 \mathrm{mg} 5$-ethyl uracil and transfer to a pear-shaped flask (15 $\mathrm{ml})$ under argon.

10| Add MeCN (1.0 ml), 1,1,1,3,3,3-hexamethyldisilazane $(0.5 \mathrm{ml})$ and TMSCl $(0.5 \mathrm{ml})$ into the flask.

11| Connect a reflux condenser to the flask and reflux the reaction mixture at $80^{\circ} \mathrm{C}$ for $1 \mathrm{~h}$ (until a clear solution is formed).

12 Cool the reaction mixture to approximately $40{ }^{\circ} \mathrm{C}$, remove the condenser, connect the flask containing 4 with an adapter and put under a vacuum pump to remove excess reagents and solvent.

13| When all reagents are evaporated, disconnect the flask from the vacuum pump and flush with argon to prevent air entering into the flask.

14| Dissolve the residue (liquid) in 1,2-dichloroethane $(4.0 \mathrm{ml})$ and transfer the solution to a sealed vial under argon.

! CAUTION Use a glove box under argon to avoid any exposure to moisture.

PAUSE POINT Store the solution at $20^{\circ} \mathrm{C}$ in a desiccator for future coupling experiments.

? TROUBLESHOOTING

Radiotracer $\left(\left[{ }^{18} \mathrm{~F}\right] \mathrm{FEAU}\right)$ production: production of ${ }^{18} \mathrm{~F}$ isotope in a cyclotron

15 Bombard $\left[{ }^{18} 0\right] \mathrm{H}_{2} \mathrm{O}(1 \mathrm{ml})$ with protons following the reaction ${ }^{18} \mathrm{O}(\mathrm{p}, \mathrm{n})^{18} \mathrm{~F}$ for $15 \mathrm{~min}$ or longer (depending on the amount of activity required), and pass the ${ }^{18} \mathrm{~F}$-enriched $\left[{ }^{18} \mathrm{O}\right] \mathrm{H}_{2} \mathrm{O}$ from the target through an anion exchange cartridge.

! CAUTION The product is radioactive. Use radiation badge and ring badge.

16| Elute the radioactive material from the cartridge with a solution of $\mathrm{K}_{2} \mathrm{CO}_{3}$ and kryptofix 2.2.2 (1.2 $\left.\mathrm{ml}\right)$ into a pre-crimped $\mathrm{v}$-vial and transfer the $\mathrm{v}$-vial to the radiochemistry lab in a hot cell (or to a FDG production box for fluorination).

Radiotracer $\left(\left[{ }^{18} \mathrm{~F}\right] \mathrm{FEAU}\right)$ production: preparation of $\left[2-{ }^{18} \mathrm{~F}\right]$ fluoro-1,3,5-tri-0-benzoyl- $\alpha$-D-arabinofuranose 2

17| Put the $\left[{ }^{18} \mathrm{~F}\right]$ fluoride obtained in Step 16 into a heating block.

! CAUTION Radioactive material, use gloves; all experiments should be performed in a hot cell.

18| Remove water from the $\left[{ }^{18} \mathrm{~F}\right]$ fluoride solution by azeotropic evaporation with dry $\mathrm{MeCN}(1-2 \mathrm{ml})$ at $110{ }^{\circ} \mathrm{C}$ under a stream of argon (dryness is observed by visualization).

19| Dissolve 2-deoxy-2-trifluoromethanesulfonyl-1,3,5-tri-0-benzoyl- $\alpha$-D-ribofuranose 1 (5 mg, stored as a shelf compound) in dry MeCN $(0.5 \mathrm{ml})$.

20| Transfer the precursor solution (Step 19$)$ to the dry $\left[{ }^{18} \mathrm{~F}\right]$ fluoride in the v-vial (Step 18) using a semi-automated box system or manual addition with manipulators.

21| Heat the reaction mixture at $80^{\circ} \mathrm{C}$ for $15 \mathrm{~min}$.

22 Cool the reaction mixture to $40{ }^{\circ} \mathrm{C}$. Connect the v-vial with a silica gel Sep-Pack cartridge (pre-treated with hexane) using Teflon tubing (approximately 2 feet long, $1 / 16$ inch i.d.).

23| Pass the reaction mixture through the Sep-Pack cartridge and discard the eluent (Fig. 3).

24| Connect the Sep-Pack to a second v-vial (Fig. 3). Elute the product with EtOAc (2 ml) into the pre-crimped v-vial (Fig. 3). ? TROUBLESHOOTING

Radiotracer $\left(\left[{ }^{18} \mathrm{~F}\right] \mathrm{FEAU}\right)$ production: preparation of $\left[2-{ }^{18} \mathrm{~F}\right]$ fluoro-1-bromo-3,5-di- 0 -benzoyl- $\alpha-\mathrm{D}$-arabinofuranose 3 25| Remove solvent from the product $2\left(\left[{ }^{18} \mathrm{~F}\right]\right.$ sugar) obtained in Step 24 by blowing a stream of nitrogen or argon at $80{ }^{\circ} \mathrm{C}$ under vacuum. 
26 Add 1,2-dichloroethane $(0.4 \mathrm{ml})$ and $\mathrm{HBr}$ in $\mathrm{AcOH}$ (30\%, $0.1 \mathrm{ml}$ ) to the dry compound 2 (through the semi-automated box system or by manual addition using manipulators), and heat the mixture for $10 \mathrm{~min}$ at $80{ }^{\circ} \mathrm{C}$ in a heating block.

27| Evaporate the solvent to $50 \%$ by volume under a stream of argon. Add 0.5-0.7 ml toluene (through the semi-automated box) and continue evaporation to dryness (visual inspection).

\section{Radiotracer $\left(\left[{ }^{18} \mathrm{~F}\right] \mathrm{FEAU}\right)$ production: coupling of the sugar} with the base; preparation of protected $\left[{ }^{18} \mathrm{~F}\right] \mathrm{FEAU} 5$

28| Add the solution of 2,4-bis-trimethylsilyl-5-ethyl uracil $\mathbf{4}$ as follows: withdraw the solution of $\mathbf{4}$ in a dry gas-tight syringe $(0.4 \mathrm{ml})$ and add to the reaction vial $\left(\left[{ }^{18} \mathrm{~F}\right]\right.$ sugar $)$ containing the 1-bromo-[2-18 $\mathrm{F}]$ fluorosugar (through the semi-automated box system or by manual addition using manipulators). After adding the protected 5-ethyl uracil 4 into the v-vial from Step 27 , heat the reaction mixture at $120^{\circ} \mathrm{C}$ for $30 \mathrm{~min}$ in a heating block.

29| Cool the reaction mixture to $80^{\circ} \mathrm{C}$ and evaporate the solvent by blowing argon or nitrogen under vacuum. ? TROUBLESHOOTING

\section{Radiotracer $\left(\left[{ }^{18} \mathrm{~F}\right] \mathrm{FEAU}\right)$ production: hydrolysis of the protecting groups; preparation of $\left.{ }^{18} \mathrm{~F}\right] \mathrm{FEAU} 6$} 30| Add $\mathrm{NaOMe}(0.1 \mathrm{ml}, 0.5 \mathrm{M}$ solution) and $\mathrm{MeOH}(0.4 \mathrm{ml})$ into the reaction vial from Step 29 (through the semi-automated box system or by manual addition using manipulators). Heat the vial containing the reaction mixture for 5 min at $80{ }^{\circ} \mathrm{C}$, and then evaporate solvent under a flow of argon or nitrogen gas and vacuum.

31 Cool and add (through the semi-automated box system or by manual addition using manipulators) $1.2 \mathrm{~mL}$ HPLC solvent (10\% MeCN/water) containing $0.1 \mathrm{ml} \mathrm{HCl}$ solution (1 M).

32 Inject the crude product onto the semi-preparative column (through the semi-automated box system or by manual addition using manipulators) pre-equilibrated with $10 \% \mathrm{MeCN}$ /water and purify the product using HPLC. Elute the column with $10 \%$

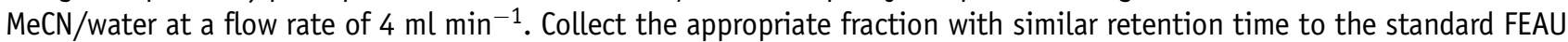
(follow radioactive peak) into a flask to obtain the desired product $\left[{ }^{18} \mathrm{~F}\right]$ FEAU 6 (Fig. 4).

33| Evaporate solvent on a rotary evaporator, re-dissolve the product in saline (2-5 ml, depending on the desired activity concentration) and filter through a Millipore filter for dose preparation.

34| Measure radioactivity on a dose calibrator (Capintec), calculate activity concentration in each dose, analyze the product on an analytical HPLC for QC and then inject the product with standard cold compound to establish its identity and purity (Fig. 5). ? TROUBLESHOOTING

\section{Radiotracer dosing and administration}

35 Prepare the radiotracer, either $\left[{ }^{18} \mathrm{~F}\right] \mathrm{FDG}$ or $\left[{ }^{18} \mathrm{~F}\right] \mathrm{FEAU}$, at a concentration of $2 \mathrm{mCi} \mathrm{ml}^{-1}\left(74 \mathrm{MBq} \mathrm{ml}^{-1}\right)$ in saline to inject the animals for PET imaging. For autoradiography, prepare a solution at a concentration of $5 \mathrm{mCi} \mathrm{ml}^{-1}\left(185 \mathrm{MBq} \mathrm{ml}^{-1}\right)$.

! CAUTION Radioactive, should be performed in a hot cell or behind lead shielding.

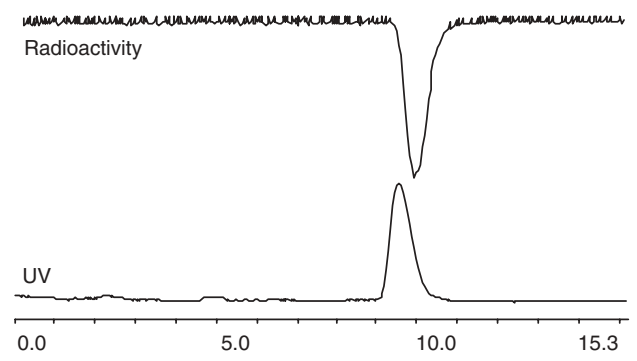

Figure 5 | QC analysis of $\left[{ }^{18} \mathrm{~F}\right] \mathrm{FEAU}$ : product injected with standard FEAU, analytical column, $10 \% \mathrm{MeCN} /$ water, flow rate $1.0 \mathrm{ml} \mathrm{min}{ }^{-1}$.

\section{Animal preparation and tumor growth}

36| Anesthetize animals (nine mice per group) by gas inhalation ( $2 \% \mathrm{vol} / \mathrm{vol}$ isoflurane in oxygen) and inject (s.c.) tumor cells of interest into the deltoid muscle area of each mouse. This will produce tumor xenografts located away from urinary system (particularly bladder), thus avoiding artifacts caused by accumulation of high activity in urine. To generate xenografts, use a tumor cell dose adequate for each line.

37| When the tumor xenograft is approximately $0.5 \mathrm{~cm}$ in diameter, inject a single i.v. dose of RGD-4C AAVP-HSV-tk as described in an accompanying protocol ${ }^{28,33}$. 
38| Take another group of tumor-bearing mice $(n=9)$ and inject them with non-targeted AAVP-HSV-tk. This group will serve as the experimental control.

\section{Animal imaging on a micro-PET using radiotracer (day 4 after AAVP injection): $\left[{ }^{18} \mathrm{~F}\right] \mathrm{FDG}$ scan \\ 39| Remove food from animal cages $5 \mathrm{~h}$ before injecting $\left[{ }^{18} \mathrm{~F}\right] \mathrm{FDG}$ for PET imaging.}

40| Anesthetize the animals by gas inhalation (2\% vol/vol isoflurane in oxygen) and inject $\left[{ }^{18} \mathrm{~F}\right] \mathrm{FDG}(100 \mu \mathrm{Ci}, 3.7 \mathrm{MBq}$, per animal) either via the caudal vein or through supra-orbital administration. Injections of $\left[{ }^{18} \mathrm{~F}\right] \mathrm{FDG}$ into the animals must be performed at an interval of 15 min to ensure a similar uptake period before imaging.

41 After [ $\left.{ }^{18} \mathrm{~F}\right]$ FDG injection, monitor the animal until full recovery from anesthesia and put back into the cage. For PET imaging, anesthetize the animal once again $55 \mathrm{~min}$ after $\left[{ }^{18} \mathrm{~F}\right] \mathrm{FDG}$ injection so that it will be ready for imaging at $1 \mathrm{~h}$ after injection.

42 Place the animal on the scanner bed on a warming pad to maintain thermal regulation, and continue administration of the anesthetic gas so that the animal cannot move during scanning. If the animal moves during imaging, clean images cannot be obtained.

43 Image the animals at $1 \mathrm{~h}$ after injection (static 15-min acquisition).

44| After scanning, remove the animal from the scanner bed and image the next animal. Continue imaging all animals in the same way. Change the absorbing pad after each animal imaging session.

\section{$\left[{ }^{18} \mathrm{~F}\right]$ FEAU scan (day 5)}

45| Scan the animals (static 15-min acquisition) using [ ${ }^{18}$ F]FEAU PET $2 \mathrm{~h}$ after injection as described above (Steps 40-44).

46 Image all animals again on day 7 and day 10 after the injection of the AAVP to determine when maximum gene expression occurs.

47| Treat the same group of animals (imaged with [ $\left.{ }^{18} \mathrm{~F}\right] \mathrm{FDG}$ and $\left.\left[{ }^{18} \mathrm{~F}\right] \mathrm{FEAU}\right)$ with ganciclovir (80 $\mathrm{mg} \mathrm{kg}^{-1} \mathrm{~d}^{-1}$, i.p.) for $3 \mathrm{~d}$ and repeat PET scans with $\left[{ }^{18} \mathrm{~F}\right] \mathrm{FEAU}$ followed by $\left[{ }^{18} \mathrm{~F}\right] \mathrm{FDG}$ before killing.

\section{Image reconstruction, analysis and interpretation}

48| Reconstruct images using a standard reconstruction protocol such as the ordered subset expectation maximization algorithm (number of iterations $=4$; number of subsets $=16$ ) with $2 \mathrm{D}$ mode, without back filter.

49| Estimate regional tumor radioactivity concentrations $\left(\mathrm{kBq} \mathrm{cm}^{-3}\right)$ from the maximum pixels within regions of interest drawn around the tumor on transaxial slices of the reconstructed image sets.

50 Ouantify radioactivity uptake $\left(\left[{ }^{18} \mathrm{~F}\right] \mathrm{FDG}\right.$ or $\left.\left[{ }^{18} \mathrm{~F}\right] \mathrm{FEAU}\right)$ in tumors and other organs as follows: draw the region of interest on images, calculate the volume and activity uptake $\left(\mathrm{nBq} \mathrm{mm}{ }^{-3}\right)$ in the region of interest and then convert into percentage injected dose per gram $\left(\% \mathrm{ID} \mathrm{g}^{-1}\right)$.

51| Calculate the mean level of activity uptake and s.d. Compare the control tissue (muscle in opposite deltoid area) and tumors. Calculate the tumor/muscle radiotracer uptake ratio between tumor and muscle by dividing the radioactivity concentration in the tumor by the radioactivity concentration in the muscle in the same animal. Calculate erythematic mean and s.d. of animal groups. In the case of non-Gaussian distribution and difference in inter-group variances, calculate medians and ranges instead.

52| Use two-tailed Student's $t$-test to compare unrelated (independent) groups with equal variances ( $F$-test) and Gaussian distribution of parameters; otherwise, use non-parametric tests (e.g., Mann-Whitney $U$-test) to compare control and treated groups.

\section{TIMING}

The procedure for production of $\left[{ }^{18} \mathrm{~F}\right] \mathrm{FEAU}$ requires approximately $3.5 \mathrm{~h}$, including bombardment for isotope production, synthesis and dose preparation. Steps 15-16: 45 min; Steps 17-18: 20 min; Steps 19-24: 30 min; Steps 25-27: 35 min; Steps 28-30: $40 \mathrm{~min}$; Steps 31-34: $45 \mathrm{~min}$. For tumor growth, injection of AAVP and imaging before and after therapy, see refs. 28,33.

\section{? TROUBLESHOOTING}

Troubleshooting advice can be found in Table 1. 
PROTOCOL

TABLE 1 | Troubleshooting table.

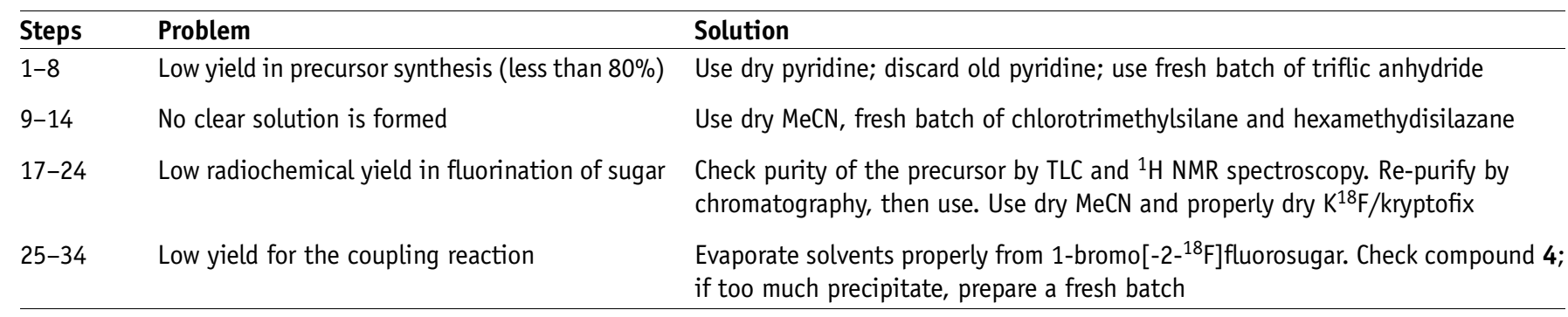

\section{ANTICIPATED RESULTS}

\section{Preparation of 2-deoxy-2-trifluoromethanesulfonyl-1,3,5-tri-0-benzoyl- $\alpha$-D-ribofuranose 1}

The overall yield for compound 1 (Steps 1-6) should be more than 95\%. In case of low yields, refer to Table 1. See NMR (analytical data); TLC: $15 \%$ acetone/hexane, $R_{\mathrm{f}}=0.5$.

\section{Preparation of 2,4-bis-trimethylsilyl-5-ethyl uracil 4}

The yield of compound 4 (Steps 9-14) is quantitative, more than 99\%. In case of low yields, refer to Table 1.

\section{Preparation of [2-18 F]fluoro-1,3,5-tri- 0 -benzoyl- $\alpha$-D-arabinofuranose 2}

The radiochemical yield in these steps (Steps 17-24) should be in the range 35-55\%. In case of low yields, refer to Table 1. Yield in the coupling reaction (Steps 25-34) should be 70-80\% (d.c.). In case of low yields, refer to Table 1.

Overall yield of [ $\left.{ }^{18} \mathrm{~F}\right] \mathrm{FEAU}$ (Steps $17-34$ ) should be $15-20 \%$ from the end of bombardment.

In a typical experiment, $10 \mathrm{mCi}(370 \mathrm{MBq})\left[{ }^{18} \mathrm{~F}\right] \mathrm{FEAU}$ is expected from $100 \mathrm{mCi}(3.7 \mathrm{GBq})\left[{ }^{18} \mathrm{~F}\right]$ fluoride.

PET images with $\left.{ }^{18} \mathrm{~F}\right] \mathrm{FDG}$ reflect tumor uptake for glucose metabolism, an indication of viable cancer cells.

PET images with [ ${ }^{18} \mathrm{~F}$ ]FEAU reflect tumor uptake for HSV1-tk gene expression at the targeted tumor, an indication of HSV1-tk gene expression. The gene product HSV1-tk (enzyme) phosphorylated [ ${ }^{18} \mathrm{~F}$ ]FEAU inside the transgene-expressing cells and ${ }^{18}$ F[FEAU] is trapped.

Maximum gene expression takes place on day 10 after the targeted AAVP vector injection.

Figure 6 is a molecular PET image of HSV1-tk targeted gene expression. The upper panel shows PET images of the control group of animals, where only uptake of FDG is observed. The lower panel shows PET images of the experimental group of animals injected with the targeting vector. PET with [ $\left.{ }^{18} \mathrm{~F}\right] \mathrm{FDG}$ reflects glucose metabolism, and PET with [ $\left.{ }^{18} \mathrm{~F}\right] \mathrm{FEAU}$ uptake reflects $\mathrm{HSV} 1$-tk gene expression. Following ganciclovir treatment, no [ $\left.{ }^{18} \mathrm{~F}\right] \mathrm{FEAU}$ uptake is observed. In contrast, some [ $\left.{ }^{18} \mathrm{~F}\right] \mathrm{FDG}$ uptake is observed, which suggests that some cancer cells remain viable following treatment, and only transduced cells are killed by the treatment.

\section{Analytical data}

Compound 1: ${ }^{1} \mathrm{H}$ NMR (300 MHz, $\left.\mathrm{CDCl}_{3}\right) \delta: 8.10-8.00(\mathrm{~m}, 6 \mathrm{H}$, aromatic), 7.76-7.65 (m, 3H, aromatic), 7.53-7.41 (m, 6H, aromatic), $6.88(\mathrm{~d}, \mathrm{~J}=4.2 \mathrm{~Hz}, 1 \mathrm{H}, \mathrm{H}-1), 5.80(\mathrm{~m}, 1 \mathrm{H}, \mathrm{H}-2), 5.56(\mathrm{~m}, 1 \mathrm{H}, \mathrm{H}-3), 4.87(\mathrm{q}, \mathrm{J}=3 \mathrm{~Hz}, 1 \mathrm{H}, \mathrm{H}-4), 4.70(\mathrm{dd}, 2 \mathrm{H}, \mathrm{H}-5)$. ${ }^{19} \mathrm{~F} \mathrm{NMR}\left(300 \mathrm{MHz}, \mathrm{CDCl}_{3}\right), \delta:-74.46(\mathrm{~s})$.

FEAU: ${ }^{1} \mathrm{H}$ NMR $\left(300 \mathrm{MHz}, \mathrm{DMSO}-\mathrm{d}_{6}\right), \delta: 10.7$ (bs, $\left.1 \mathrm{H}, \mathrm{NH}\right), 7.55$ $\left(\mathrm{s}, 1 \mathrm{H}, \mathrm{H}-6^{\prime}\right), 6.1\left(\mathrm{dd}, \mathrm{J}=14 \mathrm{~Hz}, 4 \mathrm{~Hz}, 1 \mathrm{H}, \mathrm{H}-1^{\prime}\right), 5.89$ $(\mathrm{s}, 1 \mathrm{H}, \mathrm{OH}), 5.17(\mathrm{~s}, 1 \mathrm{H}, \mathrm{OH}), 5.05\left(\mathrm{~d}, \mathrm{~J}=53 \mathrm{~Hz}, 1 \mathrm{H}, \mathrm{H}-2^{\prime}\right)$, $4.23\left(\mathrm{~d}, \mathrm{~J}=20 \mathrm{~Hz}, 1 \mathrm{H}, \mathrm{H}-3^{\prime}\right), 3.75\left(\mathrm{~d}, \mathrm{~J}=3 \mathrm{~Hz}, 1 \mathrm{H}, \mathrm{H}-4^{\prime}\right)$, 3.67-3.56 (m, 2H, $\left.\mathrm{H}-5^{\prime}\right), 2.20\left(q, J=7.4 \mathrm{~Hz}, 2 \mathrm{H}\right.$, ethyl $\left.\mathrm{CH}_{2}\right)$, $1.00\left(\mathrm{t}, \mathrm{J}=7.4 \mathrm{~Hz}, 3 \mathrm{H}\right.$, ethyl $\left.\mathrm{CH}_{3}\right)$.

${ }^{19}$ F NMR (300 MHz, DMSO- $\left.d_{6}\right), \delta:-197.2(\mathrm{~m})$.

\footnotetext{
Figure 6 | PET images (coronal) of animals (nude mice) using $\left[{ }^{18} \mathrm{~F}\right] \mathrm{FDG}$ and $\left[{ }^{18} \mathrm{~F}\right] \mathrm{FEAU}$ after vector injection. Upper panel: non-targeted AAVP-HSV-tk tumor-bearing animals imaged with $\left[{ }^{18} \mathrm{~F}\right] \mathrm{FDG}$ and $\left[{ }^{18} \mathrm{~F}\right] \mathrm{FEAU}$. Lower panel: RGD-4C AAVP-HSV-tk tumor-bearing animals imaged with [ $\left.{ }^{18} \mathrm{~F}\right] \mathrm{FDG}$ and $\left[{ }^{18} \mathrm{~F}\right] \mathrm{FEAU}$. The two left-hand images are before treatment and the two right-hand images are after treatment. $\left[{ }^{18} \mathrm{~F}\right] \mathrm{FDG}$ uptake indicates proliferating cells and $\left[{ }^{18} \mathrm{~F}\right] \mathrm{FEAU}$ uptake indicates HSV1-tk gene expression. The arrows point to tumors.
}

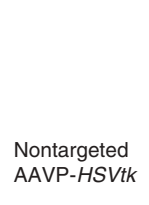
FDG

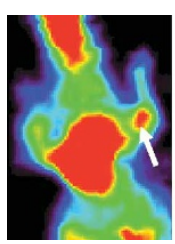
FEAU

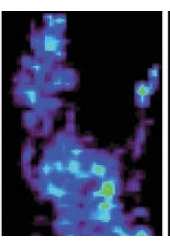

FEAU

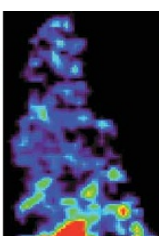

FDG
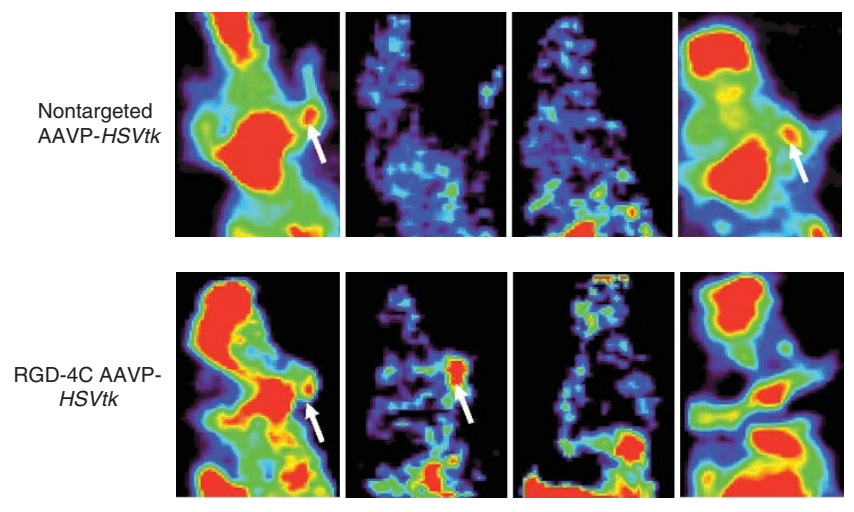

Pretreatment

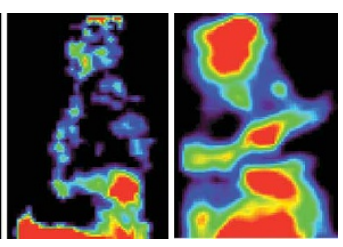

Post-treatment 
COMPETING INTERESTS STATEMENT The authors declare that they have no competing financial interests.

Published online at http://www.natureprotocols.com

Reprints and permissions information is available online at http://npg.nature.com/ reprintsandpermissions

1. Tjuvajev, J.G. et al. Imaging the expression of transfected genes in vivo. Cancer Res. 55, 6126-6132 (1995).

2. Tjuvajev, J.G. et al. Noninvasive imaging of herpes virus thymidine kinase gene transfer and expression: a potential method for monitoring clinical gene therapy. Cancer Res. 56, 4087-4095 (1996).

3. Tjuvajev, J.G. et al. Imaging herpes virus thymidine kinase gene transfer and expression by positron emission tomography. Cancer Res. 58, 4333-4341 (1998).

4. Tjuvajev, J.G. et al. Comparison of radiolabeled nucleoside probes (FIAU, FHBG, and FHPG) for PET imaging of HSV1-tk gene expression. J. Nucl. Med. 43, 1072-1083 (2002)

5. Alauddin, M.M., Conti, P.S., Mazza, S.M., Hamzeh, F.H. \& Lever, J.R. 9-[(3$\left[{ }^{18} \mathrm{~F}\right]$ fluoro-1-hydroxy-2-propoxy) methyl $]$ guanine ([$\left.\left.{ }^{18} \mathrm{~F}\right] \mathrm{FHPG}\right)$ : a potential imaging agent of viral infection and gene therapy using PET. Nucl. Med. Biol. 23 787-792 (1996)

6. Alauddin, M.M. \& Conti, P.S. Synthesis and preliminary evaluation of $9-\left(4-\left[{ }^{18} \mathrm{~F}\right]\right.$ fluoro-3-hydroxymethylbutyl)guanine ([$\left.\left.{ }^{18} \mathrm{~F}\right] \mathrm{FHBG}\right)$ : a new potential imaging agent for viral infection and gene therapy using PET. Nucl. Med. Biol. 25, 175-180 (1998).

7. Alauddin, M.M., Shahinian, A., Kundu, R.K., Gordon, E.M. \& Conti, P.S. Evaluation of 9-(3-[ $\left.{ }^{18} \mathrm{~F}\right]$-fluoro-1-hydroxy-2-propoxy)methyl guanine $\left(\left[{ }^{18} \mathrm{~F}\right]-\mathrm{FHPG}\right)$ in vitro and in vivo as a probe for PET imaging of gene incorporation and expression in tumors. Nucl. Med. Biol. 26, 371-376 (1999).

8. Alauddin, M.M., Shahinian, A., Gordon, E.M., Bading, J.R. \& Conti, P.S Pre-clinical evaluation of the penciclovir analog 9-(4- $\left[{ }^{18} \mathrm{~F}\right]$-fluoro-3hydroxymethylbutyl)guanine for in vivo measurement of suicide gene expression with PET. J. Nucl. Med. 42, 1682-1690 (2001).

9. Jacobs, A. et al. Positron emission tomography-based imaging of transgene expression mediated by replication-conditional, oncolytic herpes simplex virus type-1 mutant vectors in vivo. Cancer Res. 61, 2983-2995 (2001).

10. Haberkorn, U. et al. Monitoring gene therapy with herpes simplex virus thymidine kinase in hepatoma cells: uptake of specific substrates. J. Nucl. Med. 38, 287-294 (1997).

11. Tjuvajev, J.G. et al. Imaging adenoviral-mediated herpes virus thymidine kinase gene transfer and expression in vivo. Cancer Res. 59, 5186-5193 (1999).

12. Haberkorn, U. et al. Ganciclovir uptake in human mammary carcinoma cells expressing herpes simplex virus thymidine kinase. Nucl. Med. Biol. 25, 367-373 (1998).

13. Gambhir, S.S. et al. Imaging adenoviral-directed reporter gene expression in living animals with positron emission tomography. Proc. Natl. Acad. Sci. USA 96 2333-2338 (1999)

14. Yu, Y. et al. Quantification of gene expression by imaging reporter gene expression in living animals. Nat. Med. 6, 933-937 (2000).

15. Tjuvajev, J.G. et al. A general approach to the non-invasive imaging of transgenes using cis-linked herpes virus thymidine kinase. Neoplasia 1, 315-320 (1999).

16. Iyer, M. et al. 8-[ $\left[{ }^{18} \mathrm{~F}\right]$-Fluoropenciclovir: an improved reporter probe for imaging HSV-tk reporter gene expression in vivo using PET. J. Nucl. Med. 42, 96-105 (2001).

17. Alauddin, M.M., Fissekis, J.D. \& Conti, P.S. Synthesis of [ $\left[{ }^{18} \mathrm{~F}\right]$-labeled $2^{\prime}$-deoxy-2'fluoro-5-methyl-1- $\beta$-d-arabinofuranosyluracil ([ $\left.{ }^{18} \mathrm{~F}\right]$-FMAU). J. Labelled Compd. Radiopharm. 45, 583-590 (2002).
18. Alauddin, M.M., Shahinian, A., Gordon, E.M. \& Conti, P.S. Evaluation of 2'-deoxy2 '-fluoro-5-methyl-1- $\beta$-d-arabinofuranosyluracil as a potential gene imaging agent for HSV-tk expression in vivo. Mol. Imaging 1, 74-81 (2002).

19. Alauddin, M.M., Fissekis, J.D. \& Conti, P.S. A general synthesis of 2'-deoxy-2'$\left[{ }^{18} \mathrm{~F}\right]$ fluoro-5-methyl-1- $\beta$-d-arabinofuranosyluracil and its 5 -substituted nucleosides. J. Labelled Compd. Radiopharm. 4, 285-289 (2003).

20. Alauddin, M.M. et al. Synthesis and evaluation of $2^{\prime}-$ deoxy-2'-[18 F]- fluoro-5fluoro-1-beta-d-arabinofuranosyluracil as a potential PET imaging agent for gene expression. J. Nucl. Med. 45, 2063-2069 (2004).

21. Alauddin, M.M. et al. Synthesis of $2^{\prime}$-deoxy- $2^{\prime}-\left[{ }^{18} \mathrm{~F}\right]$ fluoro-5-bromo-1-beta-darabinofuranosyluracil $\left(\left[{ }^{18} \mathrm{~F}\right] \mathrm{FBAU}\right)$ and $2^{\prime}$-deoxy-2'-[ $\left.{ }^{18} \mathrm{~F}\right]$ fluoro-5-chloro-1-beta$\mathrm{d}$-arabinofuranosyluracil ( $\left.\left[{ }^{18} \mathrm{~F}\right] \mathrm{FCAU}\right)$, and their biological evaluation as markers for gene expression. Nucl. Med. Biol. 31, 399-405 (2004).

22. Alauddin, M.M. et al. In vivo evaluation of $2^{\prime}$-deoxy- $2^{\prime}-\left[{ }^{18} \mathrm{~F}\right]$ fluoro-5-iodo-1-betad-arabinofuranosyluracil ( $\left.\left[{ }^{18} \mathrm{~F}\right]-\mathrm{FIAU}\right)$ and $2^{\prime}$-deoxy-2'-[ $\left.{ }^{18} \mathrm{~F}\right]$ fluoro-5-ethyl-1beta-d-arabinofuranosyluracil ([ $\left.\left.{ }^{18} \mathrm{~F}\right]-\mathrm{FEAU}\right)$ as markers for suicide gene expression. Eur. J. Nucl. Med. Mol. Imaging (Jan 6 2007, E. Pub).

23. Alauddin, M.M., Shahinian, A. \& Conti, P.S. Evaluation of $2^{\prime}$-deoxy-2'-fluoro-5substituted-1-beta-d-arabinofuranosyluracils as markers for suicide gene expression in breast cancer cells. J. Nucl. Med. 46, 35 (2005).

24. Buursma, A.R. et al. ${ }^{18} \mathrm{~F}-\mathrm{FEAU}$ as a radiotracer for herpes simplex virus thymidine kinase gene expression: in vitro comparison with other PET tracers. Nucl. Med. Commun. 27, 25-30 (2006).

25. Kang, K.W., Min, J.J., Chen, X. \& Gambhir, S.S. Comparison of $\left[{ }^{14} \mathrm{C}\right] \mathrm{FMAU}$, $\left[{ }^{3} \mathrm{H}\right] \mathrm{FEAU},\left[{ }^{14} \mathrm{C}\right] \mathrm{FIAU}$ and $\left[{ }^{3} \mathrm{H}\right] \mathrm{PCV}$ for monitoring reporter gene expression with wild type and mutant herpes simplex virus type 1 thymidine kinase in cell culture. Mol. Imaging Biol. 7, 296-303 (2005).

26. Tseng, J.C. et al. Tumor specific in vivo transfection with HSV-1 thymidine kinase gene using a Sindbis viral vector as a basis for prodrug ganciclovir activation and PET. J. Nucl. Med. 47, 1136-1143 (2006).

27. Hajitou, A., Pasqualini, R. \& Arap, W. Vascular targeting: recent advances and therapeutic perspectives. Trends Cardiovasc. Med. 16, 80-88 (2006).

28. Hajitou, A. et al. A hybrid vector for ligand-directed tumor targeting and molecular imaging. Cell 125, 385-398 (2006).

29. Ivanenkov, V.V., Felici, F. \& Menon, A.G. Targeted delivery of multivalent phage display vectors into mammalian cells. Biochim. Biophys. Acta 1448, 463-472 (1999).

30. Larocca, D. et al. Gene transfer to mammalian cells using genetically targeted filamentous bacteriophage. FASEB J. 13, 727-734 (1999).

31. Poul, M.A. \& Marks, J.D. Targeted gene delivery to mammalian cells by filamentous bacteriophage. J. Mol. Biol. 288, 203-211 (1999).

32. Sergeeva, A., Kolonin, M.G., Molldrem, J.J., Pasqualini, R. \& Arap, W. Display technologies: application for the discovery of drug and gene delivery agents. $A d v$. Drug Deliv. Rev. 58, 1622-1654 (2006).

33. Hajitou, A. et al. Design and construction of targeted AAVP for mammalian cell transduction. Nat. Protoc. DOI: $10.1038 /$ nprot.2007.51.

34. Alauddin, M.M. et al. Stereospecific fluorination of 1,3,5-tri-0-benzoyl- $\alpha$-dribofuranise-2-sufonate esters: preparation of a versatile intermediate for synthesis of $2^{\prime}-\left[{ }^{18} \mathrm{~F}\right]$-fluoro-arabinonucleosides. J. Fluorine Chem. 106, 87-91 (2000)

35. Tann, C.H., Brodfuehrer, P.R., Brundidge, S.P., Sapino, C. Jr \& Howell, H.G. Fluorocarbohydrtaes in synthesis. An efficient synthesis of 1-(2-deoxy-2-fluoro$\beta$-d-arabimofuranosyluracil)-5-iodouracil ( $\beta$-FIAU) and 1-(2-deoxy-2-fluoro- $\beta$-darabimofuranosyl)thymine ( $\beta$-FMAU). J. Org. Chem. 50, 3644-3647 (1985).

36. Watanabe, K.A. et al. Nucleosides. 129. Synthesis of antiviral nucleosides: 5-alkenyl-1-(2-deoxy-2-fluoro- $\beta$-d-arabionofuranosyl)uracils. J. Med. Chem. 27, 91-94 (1984). 